\title{
Amino Acid Sequence of Bacterial Microbe-Associated Molecular Pattern flg22 Is Required for Virulence
}

\author{
Kana Naito, Fumiko Taguchi, Tomoko Suzuki, Yoshishige Inagaki, Kazuhiro Toyoda, Tomonori Shiraishi, \\ and Yuki Ichinose
}

The Graduate School of Natural Science and Technology, Okayama University, Tsushima-naka 1-1-1, Okayama 700-8530 Japan

Submitted 7 January 2008. Accepted 22 May 2008.

\begin{abstract}
Flagellin proteins derived from Pseudomonas syringae pv. tabaci 6605 and flg22 $\mathrm{Pa}$ (QRLSTGSRINSAKDDAAGLQIA), one of the microbe-associated molecular patterns (MAMP) in bacterial flagellin, induce cell death and growth inhibition in Arabidopsis thaliana. To examine the importance of aspartic acid (D) at position 43 from the N-terminus of a flagellin in its elicitor activity, D43 was replaced with valine (V) and alanine (A) in $P$. syringae pv. tabaci flagellin and flg22 Pta The abilities of flagellins from $P$. syringae $\mathrm{pv}$. tabaci D43V and D43A to induce cell death and growth inhibition were reduced, whereas the abilities of flg22 $2_{\mathrm{Pta}} \mathrm{D} 43 \mathrm{~V}$ and flg22 $\mathrm{Pta}_{\mathrm{D}} \mathrm{D} 3 \mathrm{~A}$ were abolished. These results indicate that $\mathrm{D43}$ is important for elicitor activity in $P$. syringae pv. tabaci. When tobacco plants were inoculated with each bacterium by the spray method, both $P$. syringae pv. tabaci D43V and D43A mutants had remarkably reduced ability to cause disease symptoms. Both mutants had reduced or no swimming and swarming motilities and adhesion ability. In $P$. syringae pv. tabaci D43V, little flagellin protein was detected and few flagella were observed by electron microscopy. These results indicate that mutant flagella are unstable and that flagellar motility is impaired. Thus, the amino acid residue required for MAMP activity is important for the intrinsic flagellar function.
\end{abstract}

Additional keywords: flagellin glycosylation, FLS2, PAMPs.

Plants have evolved two types of defense systems against invasion by pathogens (Bent and Mackey 2007). One of the systems is based on the gene-for-gene theory and occurs as a result of the direct or indirect interactions between avirulence (Avr) proteins produced by pathogens and resistance $(R)$ gene products of host plants. Another is an innate immune system triggered by recognition of the molecules present in microbes independently of incompatible race-cultivar interactions. These molecules were originally termed elicitors and recently are called pathogen-associated molecular patterns (PAMPs). PAMPs include fungal chitin and ergosterol, oomycete-derived $\beta$-glucans and transglutaminase, bacterial lipopolysaccharide (LPS), cold-shock protein, elongation factor Tu, and flagellin (Bittel and Robatzek 2007; Nürnberger et al. 2004). Because PAMPs do not always originate from pathogenic microbes,

Corresponding author: Yuki Ichinose; Telephone/Fax: +81 86-251-8308; E-mail: yuki@cc.okayama-u.ac.jp

* The $\boldsymbol{e}$-Xtra logo stands for "electronic extra" and indicates that a supplementary figure is published online. they should be designated microbe-associated molecular patterns (MAMPs). The molecules comprising MAMPs are abundant in microbes. Thus, most MAMPs recognized by plants correspond to molecules that are essential for microbial life but do not necessarily play a role in pathogenicity (Bittel and Robatzek 2007).

The best-characterized set of a MAMP and MAMP receptor is flg22 in flagellin and FLS2 in Arabidopsis thaliana. Flagellin constitutes the flagellar filament and is the most abundant extracellular protein in bacteria. Felix and associates (1999) found an elicitor activity in the N-terminal fragment of flagellin and synthesized a 22-amino-acid peptide (flg22) spanning the conserved domain in gram-negative bacteria based on the sequence of Pseudomonas aeruginosa (Fig. 1). Flg22 stimulates defense responses such as alkalinization of the extracellular medium, generation of reactive oxygen species (ROS), pathogenesis-related $(P R)$ gene expression, callose deposition, and growth inhibition in Arabidopsis and tomato (Felix et al. 1999; Gómez-Gómez et al. 1999). Functional dissection of flg22 revealed that flg15, the C-terminal part of flg22, was the smallest and most active peptide in tomato but not in Arabidopsis (Felix et al. 1999). Furthermore, several structural analogues of flg 15 with replacements of a single amino acid residue with alanine revealed that the sequence Asp-Asp-Ala (43rd to 45th from the N-terminus) in the middle of flg 15 is important for alkalinization-inducing activity in suspensioncultured tomato cells (Felix et al. 1999). Perception of flg22 is mediated by its receptor molecule FLS2 in Arabidopsis (Chinchilla et al. 2006; Gómez-Gómez and Boller 2000). FLS2 has an extracellular leucine-rich repeat (LRR) domain and an intracellular protein kinase domain, one of the typical MAMP recognition receptors. In the recognition of flagellin, the first step is binding the N-terminus of flg 15 to the receptor, and the second step is activation of responses from the C-terminus (Meindl et al. 2000). The Asp-Asp-Ala sequence was also shown to be indispensable for binding activity (Meindl et al. 2000).

Recently, it was reported that an amino acid sequence for flg22 in Xanthomonas campestris pv. campestris is important for the defense response in Arabidopsis (Sun et al. 2006). Bacterial strains such as $X$. campestris pv. campestris B305, the flagellin of which has D43, elicited Arabidopsis defense responses, whereas strains such as $X$. campestris pv. campestris B186 with V43 did not. Thus, inoculation of Arabidopsis Col0 plants with these $X$. campestris pv. campestris strains by vacuum infiltration resulted in severe disease symptoms in B186-inoculated leaves but not in B305-inoculated leaves. Sun and associates (2006) investigated indispensable amino acid residues for flagellin-triggered defense responses in Arabidop- 
sis using various kinds of recombinant flagellin polypeptides and found that a single amino acid, D43, was a key determinant of elicitor activity. However, bacterial propagation of B305 and B186 is independent of the presence of FLS2. Namely, B186 propagated well in both Col-0 and the $f l s 2$ mutant to the same extent, whereas B305 propagated less well in both Col- 0 and the $f l s 2$ mutant, also to the same extent. As one of the explanations of this phenomenon, Sun and associates (2006) hypothesized that $X$. campestris pv. campestris bacteria do not produce enough flagellin monomers in leaves to induce the host defense response. Indeed, the motility of all $X$. campestris pv. campestris strains used in this study was very low compared with that of $P$. syringae pv. tomato. Therefore, it was difficult to evaluate the importance of D43 in flagellin in interactions between plants and motility-impaired bacteria.

We have also found elicitor activity in flagellins from $P$. syringae pv. tabaci 6605 , pv. glycinea race 4 , and pv. tomato DC3000 (Taguchi et al. 2003b). Furthermore, we found that the flagellins of $P$. syringae pathovars are glycoproteins, and that the glycosylation of flagellin affects its motility, virulence, and ability to induce the hypersensitive response (HR) (Taguchi et al. 2003a, 2006; Takeuchi et al. 2003). Flagellins from $P$. syringae induce HR in nonhost plants (Taguchi et al. 2003b, 2006). However, the amino acid sequences of flagellins from $P$. syringae pathovars are very similar. In particular, the flagellins from $P$. syringae pvs. tabaci and glycinea have identical amino acid sequences, although each flagellin possesses a distinct elicitor activity on tobacco and soybean (Taguchi et al. $2003 \mathrm{~b}, 2006)$. These results indicate that glycosylation may determine the species-specific ability to induce HR. The importance of flagellin glycosylation was also supported by a study using recombinant whole-flagellin proteins expressed in Escherichia coli. All recombinant flagellins lost their specificity for HR induction (Taguchi et al. 2003b), indicating that they also lost pathovar-specific post-translational modification. Furthermore, a study using recombinant flagellin polypeptides indicated that the $\mathrm{N}$-terminal domain including the conserved flg22 is required for flagellin-induced hypersensitive cell death in Arabidopsis (Naito et al. 2007). To evaluate the significance of the conserved amino acids in flg22 for induction of defense response and virulence, the study of recombinant flagellins is not sufficient. It is necessary to examine the effect of amino acid substitutions in flg22 in the bacteria in which flagella are important for virulence. Because $P$. syringae pv. tabaci 6605 is highly motile (Taguchi et al. 2006) and we had previously
30

flg15 $5_{P a}$

flg22 $2_{P a}$ :

flg22 $2_{P t a}$ L43S:

flg22 $2_{\text {Pta }}$ K37R:

flg22 $2_{P t a}:$

flg22 $2_{\text {ta }} \mathrm{D} 43 \mathrm{~A}$ :

flg22 $2_{P t a} \mathrm{D} 43 \mathrm{~V}$ :

flg22 2 ссв305:

flg22 2 СcB186:
43

RINSAKDDAAGLQIA

QRLSTGSRINSAKDDAAGLQIA

TRLSSGSKINSAKDDAAGLQIA

TRLSSGLRINSAKDDAAGLQIA

TRLSSGLKINSAKDDAAGLQIA

TRLSSGLKINSAKADAAGLQIA

TRLSSGLKINSAKVDAAGLQIA

QRLSSGLRINSAKDDAAGLAIS

\section{QQLSSGKRITSASVDAAGLAIS}

Fig. 1. Flg22 and flg22-derived amino acid sequences in gram-negative bacteria. Pta: Pseudomonas syringae pv. tabaci 6605, Xcc: Xanthomonas campestris pv. campestris, Pa: Pseudomonas aeruginosa. The 43rd amino acid residue of each and 36th and 37th amino acid residues in flg22 $\mathrm{Pa}$ and flg $22_{\mathrm{Pta}}$ are indicated by a bold letter. confirmed that flagellar motility is required for virulence by analysis of the flagella-defective mutants $\Delta$ fliC and $\Delta$ fliD (Ichinose et al. 2003), this pathogen provides a suitable model for the analysis.

Flagellin from $P$. syringae pv. tabaci 6605 retains D43 in the flg22 region (Fig. 1). To examine the importance of D43 in the elicitor activity of flagellin, we generated mutant strains in which the 43rd residue (aspartic acid) was replaced with valine $(\mathrm{D} 43 \mathrm{~V})$ or alanine (D43A) residues in the flagellin in $P$. syringae pv. tabaci 6605 and investigated the virulence of these mutants. We also introduced the mutation into L36 and K37, in which amino acid residues are different between $P$. aeruginosa and $P$. syringae pv. tabaci. Based on the results obtained with mutant strains, we discuss the MAMP activity of flagellin and its relationship to the intrinsic function of the flagellum.

\section{RESULTS}

\section{Generation of D43-substituted mutants} in $P$. syringae pv. tabaci.

To investigate the importance of D43 in the flg 22 region, the genetic code for D43 (GAT) was converted to valine (GTT) and alanine (GCT). The site-specific mutations of the fliC gene in the resultant strains were confirmed by polymerase chain reaction (PCR) and sequencing. Then, the mutated $\mathrm{fliC}$ gene was introduced into $P$. syringae pv. tabaci by conjugation and homologous recombination, as below. The reproduction rate of the mutants did not differ from that of the wild-type strain (Supplementary Fig. 1).

\section{Effect of D43 substitution on induction of cell death in Arabidopsis leaves.}

To analyze the effect of the amino acid substitution, we assayed cell death in Arabidopsis leaves using purified flagellins and flg22 oligopeptides. The left halves of $A$. thaliana ecotype Col-0 leaves were infiltrated with flagellins from $P$. syringae pv. tabaci wild type, D43V and D43A mutants, flg22 of $P$. aeruginosa (flg22 2 ) and $P$. syringae pv. tabaci $\left(\right.$ flg2 $22_{\mathrm{Pta}}$ ), and flg22 $2_{\mathrm{Pta}}$ derivatives (flg22 $2_{\mathrm{Pta}} \mathrm{D} 43 \mathrm{~V}$ and flg22 $2_{\mathrm{Pta}} \mathrm{D} 43 \mathrm{~A}$ ) by a syringe-infiltration method. After $24 \mathrm{~h}$ of treatment with flagellin or flg22, the dead cells in the treated leaves were stained with trypan blue as described below. Areas infiltrated with flg22 and flg22 $\mathrm{Pta}$ at concentrations of 0.1 and $2 \mu \mathrm{M}$ were stained with trypan blue, indicating cell death, but the infiltration with mutated oligopeptides flg $22_{\mathrm{Pta}} \mathrm{D} 43 \mathrm{~V}$ and flg22 $2_{\mathrm{Pta}} \mathrm{D} 43 \mathrm{~A}$, even at the concentration of $2 \mu \mathrm{M}$, did not cause staining (Fig. 2). On the other hand, treatment with flagellin from $P$. syringae pv. tabaci wild-type strain caused dark staining even at $0.1 \mu \mathrm{M}$, indicating much cell death, and treatment with flagellin from P. syringae pv. tabaci D43V and D43A mutants caused light staining, indicating a low level of cell death at $2 \mu \mathrm{M}$ and no staining at $0.1 \mu \mathrm{M}$ (Fig. 2). These results suggest that the D43 residue in flg22 is important for the induction of not only seedling growth inhibition and $P R-1$ gene expression, as previously reported by Sun and associates (2006), but also cell death.

\section{Growth inhibition by flagellin and flg22 and their derivatives in Arabidopsis seedlings.}

To examine the effect of the amino acid substitution, we performed a growth inhibition assay on Arabidopsis seedlings using flagellin proteins and flg22 oligopeptides. Five-day-old Arabidopsis seedlings were treated with $0.1 \mu \mathrm{M}$ flagellin or flg22 for 7 days at $24^{\circ} \mathrm{C}$, and the seedlings were weighed. The inhibitory effect of flagellins and flg22 on Arabidopsis growth was prominent in the treatment with flagellin from $P$. syringae pv. tabaci wild-type strain (Fig. 3A and B). The treatments of Arabidopsis with the wild-type flagellin, flg $22_{\mathrm{Pa}}$ and flg22 $2_{\mathrm{Pta}}$, 
strongly inhibited growth, whereas the mutated flg22, flg22 $2_{\mathrm{Pta}} \mathrm{D} 43 \mathrm{~V}$ and flg22 $2_{\mathrm{Pta}} \mathrm{D} 43 \mathrm{~A}$, had no inhibitory activity. The mutated flagellins from D43V and D43A allowed root elongation in water, although the fresh weight of the seedlings was slightly less than that of control seedlings. Comparison of the results of treatments with flg $22_{\mathrm{Pa}}$ and flg $22_{\mathrm{Pta}}$ indicates that flg22 $\mathrm{Pa}$ inhibited Arabidopsis growth more effectively. Treatments with flagellins from $P$. syringae pv. tabaci wild-type strain, D43-substituted mutant strains, and flg22 oligopeptides with or without D43 substitutions on the Arabidopsis fls 2 mutant produced no growth inhibition, indicating that the Arabidopsis response was dependent on FLS2 (Fig. 3C and D).

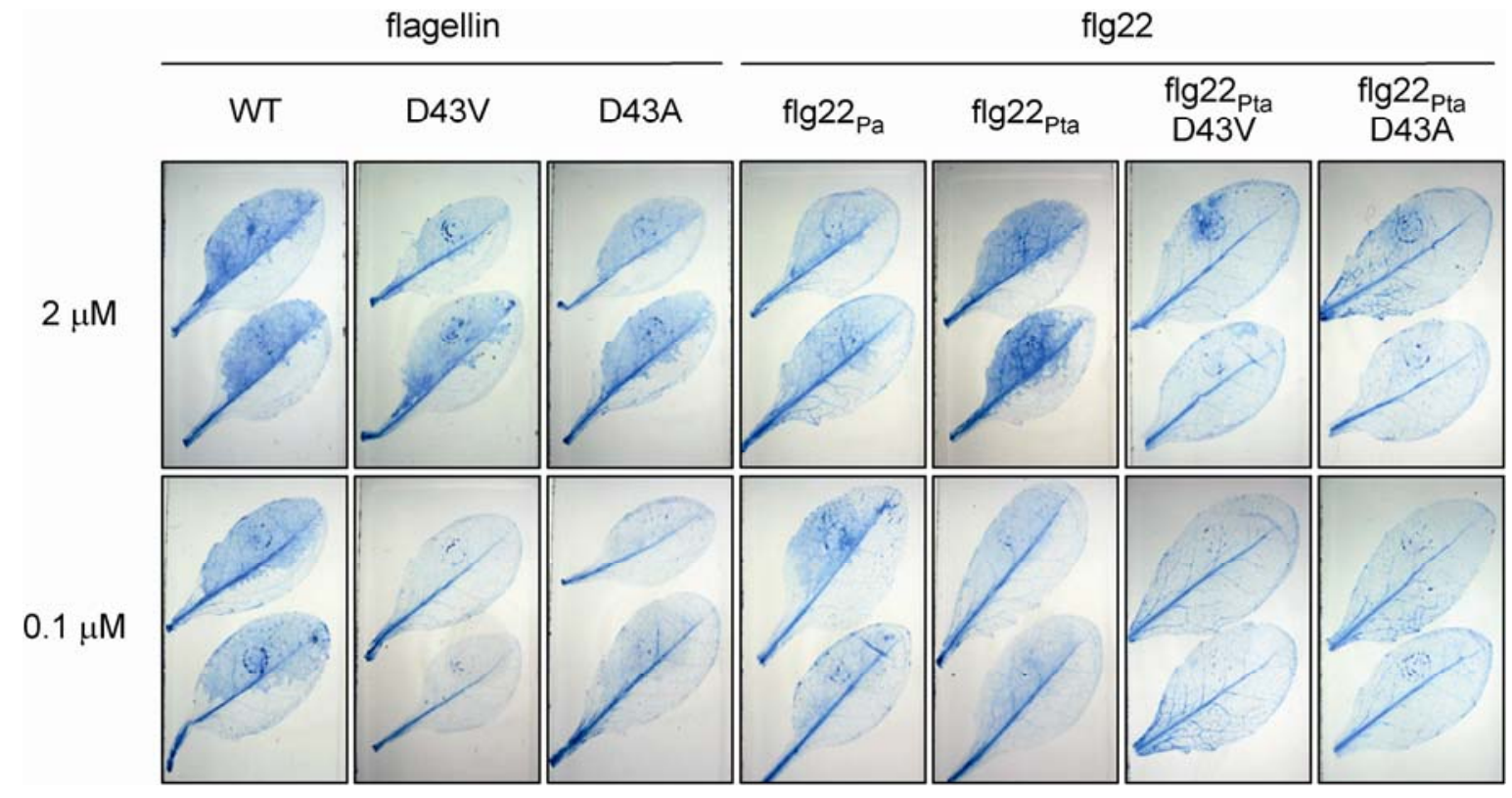

Fig. 2. Flagellin- and flg22-induced cell death in Arabidopsis thaliana. The left halves of leaves of Arabidopsis ecotype Col-0 were infiltrated with flagellins from Pseudomonas syringae pv. tabaci wild-type (WT), D43V and D43A mutants, and flg 22 derivatives by the infiltration method, and incubated at $22^{\circ} \mathrm{C}$ for $24 \mathrm{~h}$. Then, the leaves were stained by trypan blue. The concentration of flagellins and flg22 derivatives was $2 \mu \mathrm{M}$ in the upper panels and $0.1 \mu \mathrm{M}$ in the lower panels. Photos are representative results obtained from two to four independent experiments. The syringe marks are sometimes stained artificially as dark spots.

A
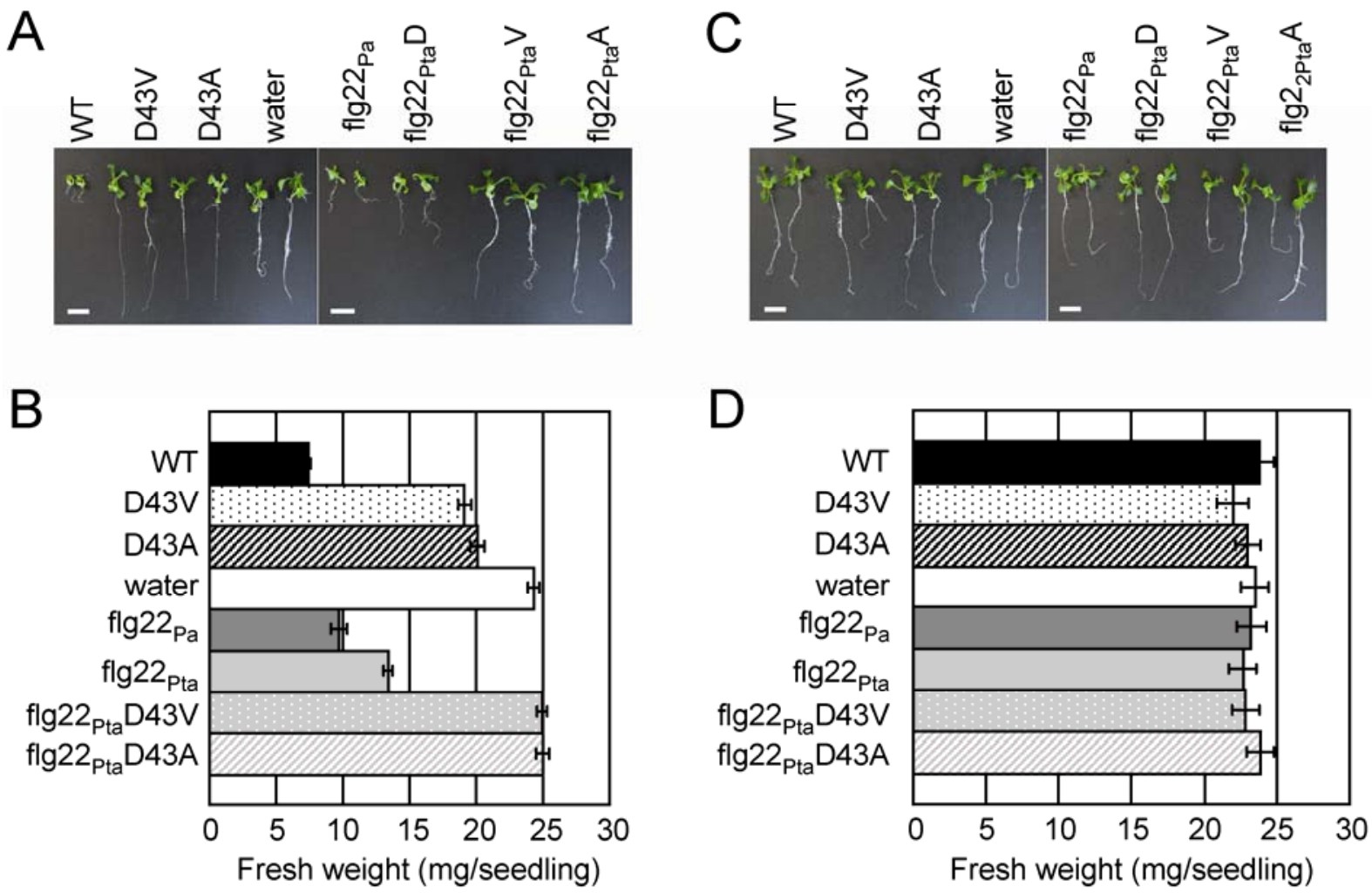

Fig. 3. Flagellin- and flg22-induced growth inhibition in Arabidopsis thaliana. Arabidopsis seedlings of $\mathbf{A}$ and $\mathbf{B}$, Col-0 wild type (WT) and $\mathbf{C}$ and $\mathbf{D}$, Col-0 fls 2 mutant were incubated in Murashige-Skoog liquid medium with $0.1 \mu \mathrm{M}$ flagellin or flg22 for 7 days. As a control, water was used instead of flagellin or flg22. After 7 days of incubation, representative seedlings were photographed (A and C). The white bar indicates $1 \mathrm{~cm}$. Fresh weights (means with standard error) of 30 independent seedlings were measured (C and D). 
Flagellin- and flg22-induced activation of senescence-induced receptor-like kinase promoter in A. thaliana.

The flg22-induced receptor-like kinase 1 (FRK1; At2g19190) is reported to be one of the Arabidopsis genes that responds strongly to treatment with flg22 (Asai et al. 2002). Because the expression of $F R K 1$ is strongly induced during leaf senescence, FRK1 is also designated SIRK (senescence-induced receptor-like kinase) (Robatzek and Somssich 2002). The leaves of transgenic Arabidopsis plants expressing the $\beta$-glucuronidase (GUS) reporter gene (uidA from E. coli) under the control of an AtSIRK promoter were infiltrated with $0.1 \mu \mathrm{M}$ flagellin or flg22. After $24 \mathrm{~h}$ of incubation at $22^{\circ} \mathrm{C}$, GUS activity in the protein extracts was fluorometrically measured. The wild-type flagellin was the strongest inducer of GUS activity (9 nmol of 4-methylumbelliferone [4-MU]) produced per milligram of protein per minute) (Fig. 4A). Infiltration of leaves with water and two mutated flg22, flg22 $2_{\mathrm{Pta}} \mathrm{D} 43 \mathrm{~V}$ and flg22 $2_{\mathrm{Pta}} \mathrm{D} 43 \mathrm{~A}$, did not induce any GUS activity, whereas the leaves infiltrated with mutated flagellins D43V and D43A and flg22 from $P$. syringae pv. tabaci and $P$. aeruginosa induced low levels of GUS activity. Among the treatments with flagellins and flg22, the induction of GUS activity by flg22 $2_{\mathrm{Pta}} \mathrm{D} 43 \mathrm{~V}$ and flg $22_{\mathrm{Pta}} \mathrm{D} 43 \mathrm{~A}$ was lower than that by the other treatments (Fig. 4A). Interestingly we observed that the higher the concentration $(2 \mu \mathrm{M})$ of flagellins $\mathrm{D} 43 \mathrm{~V}$ and D43A used, the higher the GUS activity appeared to be. However the mutated flg22 peptides, flg22 $2_{\mathrm{Pta}} \mathrm{D} 43 \mathrm{~V}$ and flg22 $2_{\mathrm{Pta}} \mathrm{D} 43 \mathrm{~A}$, did not induce GUS activity even at high concentrations $(2$ and $10 \mu \mathrm{M})$. On the other hand, dose-dependent GUS activity was observed at the concentrations of $\mathrm{flg} 22_{\mathrm{Pa}}$ and flg22 2 pta between 0.1 and $10 \mu \mathrm{M}$. This suggests that the biologically relevant flagellin protein may interact with the FLS2 receptor in ways that flg22 does not. The histochemical staining of GUS expression in infiltrated leaf disks was consistent with the fluorometric measurement (Fig. 4). Flagellin from $P$. syringae pv. tabaci wild-type strain caused dark staining indicating strong expression of the SIRK promoter, whereas treatment with water, flg22 $2_{\mathrm{Pta}} \mathrm{D} 43 \mathrm{~V}$, and flg22 $2_{\mathrm{Pta}} \mathrm{D} 43 \mathrm{~A}$ caused no staining, indi- cating that flg22 $2_{\mathrm{Pta}} \mathrm{D} 43 \mathrm{~V}$ and flg22 $2_{\mathrm{Pta}} \mathrm{D} 43 \mathrm{~A}$ are not active elicitors. Furthermore, treatments with flagellins with D43V, D43A, and flg 22 from $P$. syringae pv. tabaci and $P$. aeruginosa induced light staining, indicating that the elicitor activities of these flagellins and flg22 were lower than that of the wild-type flagellin (Fig. 4B).

\section{Loss of virulence in D43V-and D43A-substituted P. syringae pv. tabaci mutants.}

The evidence that D43 is important for the elicitor activity of flagellin and flg22 led us to speculate that D43V- and D43A-substituted mutants might cause more severe disease symptoms in their host tobacco plant. To investigate the effects of the replacements $\mathrm{D} 43 \mathrm{~V}$ and $\mathrm{D} 43 \mathrm{~A}$ on virulence, tobacco leaves were inoculated with $P$. syringae pv. tabaci wild-type, $\mathrm{D} 43 \mathrm{~V}, \mathrm{D} 43 \mathrm{~A}$, and $\Delta f l i C$ mutants by the spray method. The wild type caused typical wildfire disease in tobacco, whereas the D43V and D43A mutants did not cause severe disease symptoms (Fig. 5A). Further, we observed that the $\Delta f l i C$ mutant did not cause any visible change. The reduction of virulence in D43V and D43A mutants was also observed by the infiltration-inoculation method (Fig. 5C). The bacterial propagation of both $P$. syringae pv. tabaci D43A and D43V mutant strains was reduced compared with that of wild-type propagation but higher than that of the $\Delta f l i C$ mutant in the sprayinoculated tobacco leaves (Fig. 5B). However, the reduction of bacterial growth of $\mathrm{D} 43 \mathrm{~V}$ and $\mathrm{D} 43 \mathrm{~A}$ mutants was not as obvious in the infiltrated tobacco leaves (Fig. 5D).

\section{D43 is important for bacterial motility and adhesion in $P$. syringae pv. tabaci.}

Flagellar motility-defective mutants such as the $\Delta f l i C$ and $\Delta$ fliD mutants of $P$. syringae pv. tabaci are known to have no or reduced virulence on tobacco plants (Ichinose et al. 2003). Furthermore, $\Delta f g t 1(\Delta o r f 1)$ and $\Delta f g t 2(\Delta o r f 2)$ flagellin-glycosylation-defective mutants were impaired in motility, virulence, and adhesion ability (Taguchi et al. 2006). The flagellar swimming and swarming motilities (Fig. 6A and B) and adhesion
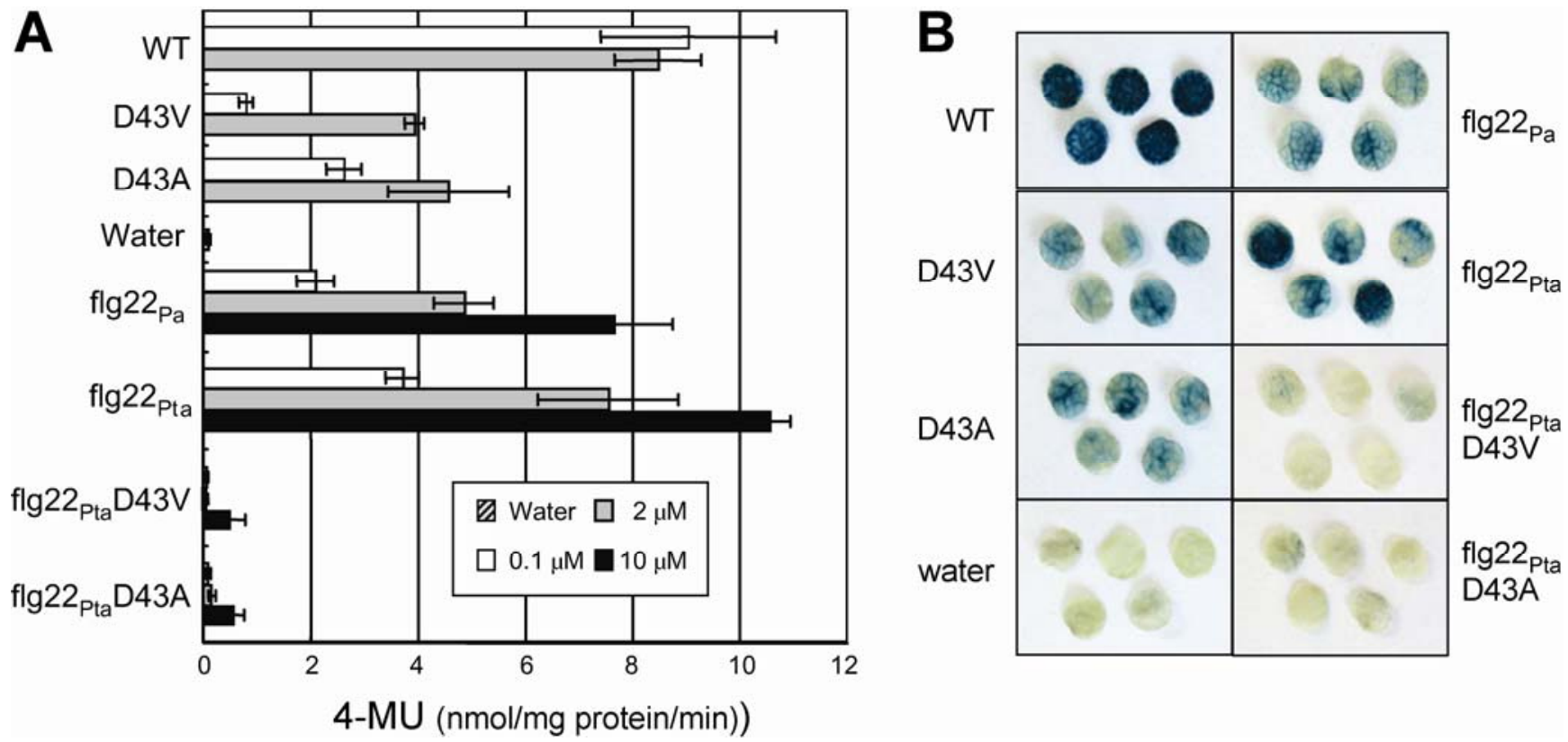

Fig. 4. Flagellin- and flg22-induced activation of senescence-induced receptor-like kinase (SIRK) promoter in Arabidopsis thaliana. $\beta$-Glucuronidase (GUS) activity derived from Arabidopsis SIRK promoter in response to flagellin and flg22 was measured after $24 \mathrm{~h}$ of treatment. A, Flagellin proteins and flg22 peptides were infiltrated into the leaves at $0.1 \mu \mathrm{M}$ (white boxes), $2 \mu \mathrm{M}$ (gray boxes), and $10 \mu \mathrm{M}$ (black boxes), and GUS activity was fluorometrically measured. B, Leaves infiltrated with $0.1 \mu \mathrm{M}$ flagellin or flg22 were histochemically stained. Experiments using five leaf disks were repeated five times. Photos depict representative results. 
ability (Fig. 6C) of the D43-substituted mutants were compared with those of the wild-type strain. D43V was defective in all three assays and D43A was also significantly defective but more functional.

\section{Effect of D43 substitution on flagella formation.}

To investigate flagella formation, we first detected flagellin protein from the cells of bacteria cultured overnight. Bacteria were harvested by centrifugation and total proteins corresponding to approximately $4 \times 10^{8}$ bacterial cells were dissolved and subjected to $12 \%$ sodium dodecyl sulfate polyacrylamide gel electrophoresis (SDS-PAGE). Flagellin protein was detected by Western blotting analysis using a flagellinspecific antibody (Fig. 7A). Although the amounts of flagellin protein in $P$. syringae pv. tabaci wild type and D43A mutant were nearly the same, that in the D43V mutant was less. Electron microscopic observation revealed that $P$. syringae pv. tabaci wild-type (Fig. 7B) and D43A mutant strains (Fig. 7D) retained three to five long flagella. However, many cells of
D43V mutant did not possess flagella and some cells possessed only one to two short flagella per cell (Fig. 7C).

\section{Effects of L36 and K37 substitutions}

on elicitor activity, virulence, and motilities.

The study using the mutant strains D43V and D43A demonstrated that D43, an important epitope for elicitor activity in flg22, is required for both motility and virulence. To confirm this conclusion, we newly introduced the mutation into L36 and K37 and generated the mutant strains L36S and K37R. Because the 36th and 37th amino acid residues are Leu-Lys in $P$. syringae pv. tabaci and Ser-Arg in P. aeruginosa, we expected that the substitution of amino acid residues in the flg22 region of $P$. syringae pv. tabaci and $P$. aeruginosa would not affect their motility, virulence, or elicitor activity in purified flagellin. Although the ability of the flagellins from the L36S mutant to induce GUS activity was a little weaker than that of the wild-type flagellin, they still retained remarkable elicitor activity (Fig. 8A). Further, the elicitor activity of the
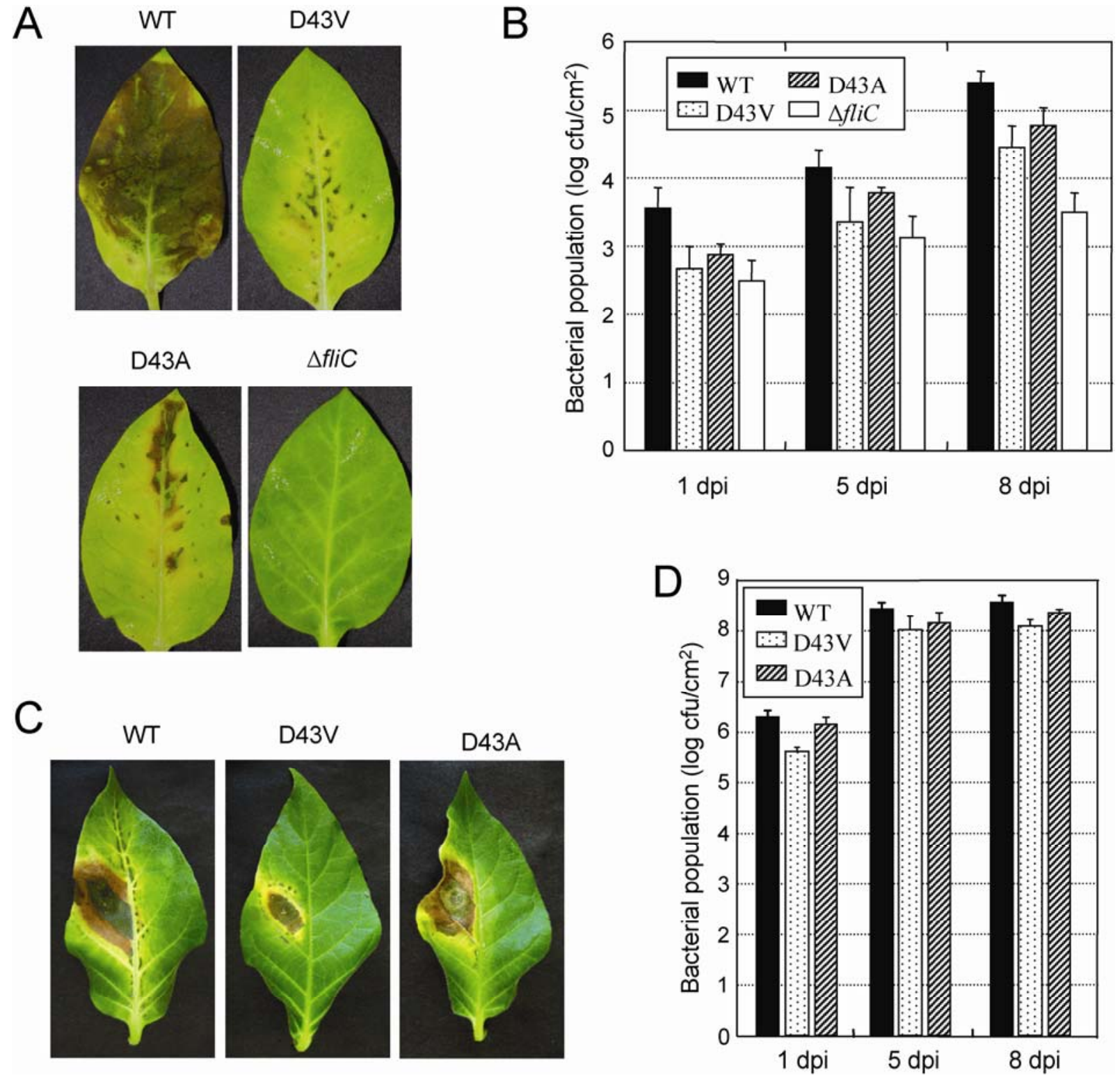

Fig. 5. Loss of virulence in Pseudomonas syringae pv. tabaci D43V and D43A mutants in tobacco. Tobacco leaves were $\mathbf{A}$ and $\mathbf{B}$, spray inoculated with $2 \times$ $10^{8} \mathrm{CFU} / \mathrm{ml}$ or $\mathbf{C}$ and $\mathbf{D}$, infiltration inoculated with $2 \times 10^{5} \mathrm{CFU} / \mathrm{ml}$ and incubated at $23^{\circ} \mathrm{C}$ for $\mathbf{A}, 11$ and $\mathbf{C}, 10$ days. Bacterial populations were measured at 1,5 , and 8 days post inoculation (dpi) by the $\mathbf{B}$, spray method or $\mathbf{D}$, infiltration method. Bacterial strains are P. syringae pv. tabaci wild-type (WT), D43V, $\mathrm{D} 43 \mathrm{~A}$, and $\triangle \mathrm{fliC}$ mutant strains. The bars represent standard deviations for at least three independent experiments. 
flagellin from the K37R mutant was at a level similar to that of the wild-type strain. The mutant strains L36S and K37R also caused severe disease symptoms on tobacco leaves (Fig. 8B) and showed strong motility in swimming (Fig. 8C) and swarming (Fig. 8D) tests. These results confirmed that the mutant strains with motility, such as L36S and K37R, are virulent on tobacco leaves and that the flagellin purified from these mutants actively induces a defense response, whereas the mutant strains without any or with lower motility, such as D43V and $\mathrm{D} 43 \mathrm{~A}$, are less virulent on tobacco, and flagellin purified from these mutants is less active in inducing a defense response.

\section{DISCUSSION}

In this article, we report that the amino acid residue in flagellin required for MAMP activity is important for the intrinsic function of the flagellum in $P$. syringae pv. tabaci 6605 . The amino acid sequence of the best-known MAMP, flg22 2 , is widely conserved in many gram-negative bacteria (Felix et al. 1999). However, the amino acid sequence of the flg 22 region in some bacterial species is less conserved, and some, such as Agrobacterium tumefaciens, Rhizobium meliloti (Felix et al. 1999), and Ralstonia solanacearum (Pfund et al. 2004), do not show any elicitor activity. The importance of the flg 22 region of $X$. campestris pv. campestris in the elicitor activity was further investigated using recombinant flagellin polypeptides. Thus, recombinant flagellin from $X$. campestris pv. campestris strain B305 possessing D43 elicited a defense response in Arabidopsis but that from $X$. campestris pv. campestris strain B186 possessing V43 did not (Sun et al. 2006). These results indicate that the flg22 region is a typical MAMP and that D43 is important for recognition by Arabidopsis.

In the case of $P$. syringae, we have found strong elicitor activity in purified flagellin proteins from $P$. syringae pv. tabaci $6605, P$. syringae pv. glycinea race 4 , and $P$. syringae pv. tomato DC3000 (Taguchi et al. 2003b). The flg22 regions
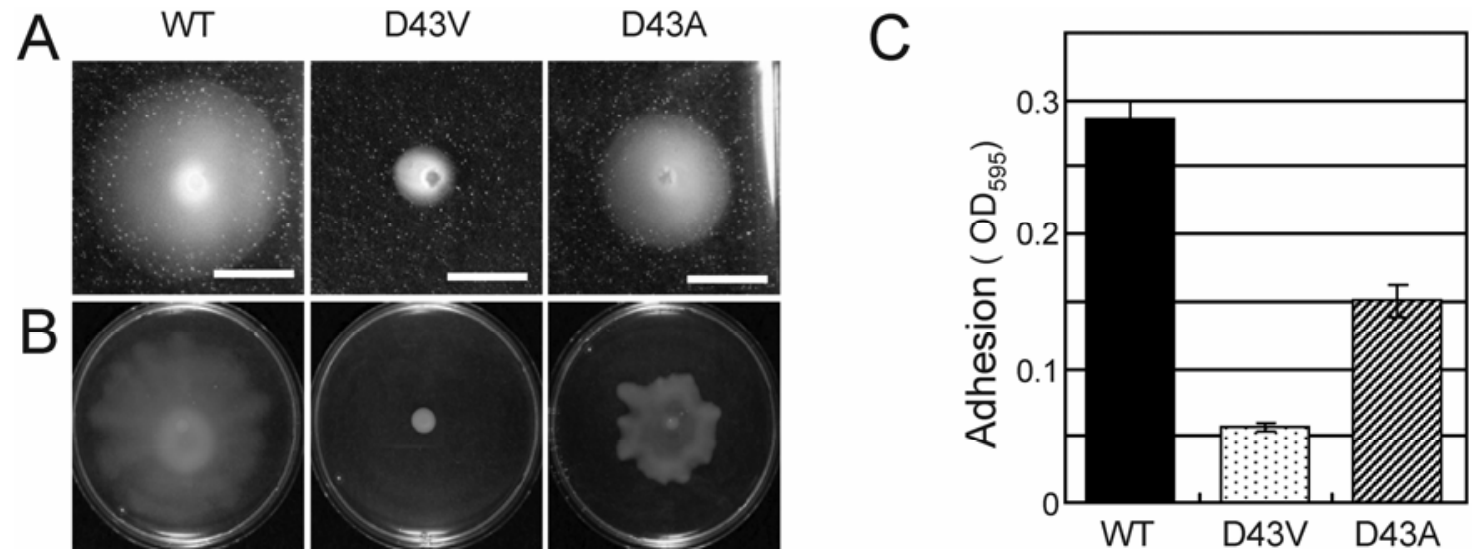

Fig. 6. Bacterial motility and adhesion ability. Bacterial cell densities were adjusted to an optical density at $660 \mathrm{~nm}\left(\mathrm{OD}_{660}\right)$ of 0.3 with $\mathrm{MMMF}$ medium, and 3- $\mu 1$ aliquots were inoculated on the center of MMMF (0.25\% agar) and SWM agar $(0.5 \%$ agar) plates for swimming and swarming assays, respectively. The photographs were taken 2 and 1 days after inoculation for $\mathbf{A}$, swimming and $\mathbf{B}$, swarming assays, respectively. The bar in A is $1 \mathrm{~cm}$. $\mathbf{C}$, Adhesion ability. Each experiment was repeated three times, and typical results were shown in A and B. In C, values represent means and standard errors $(P<0.05)$.

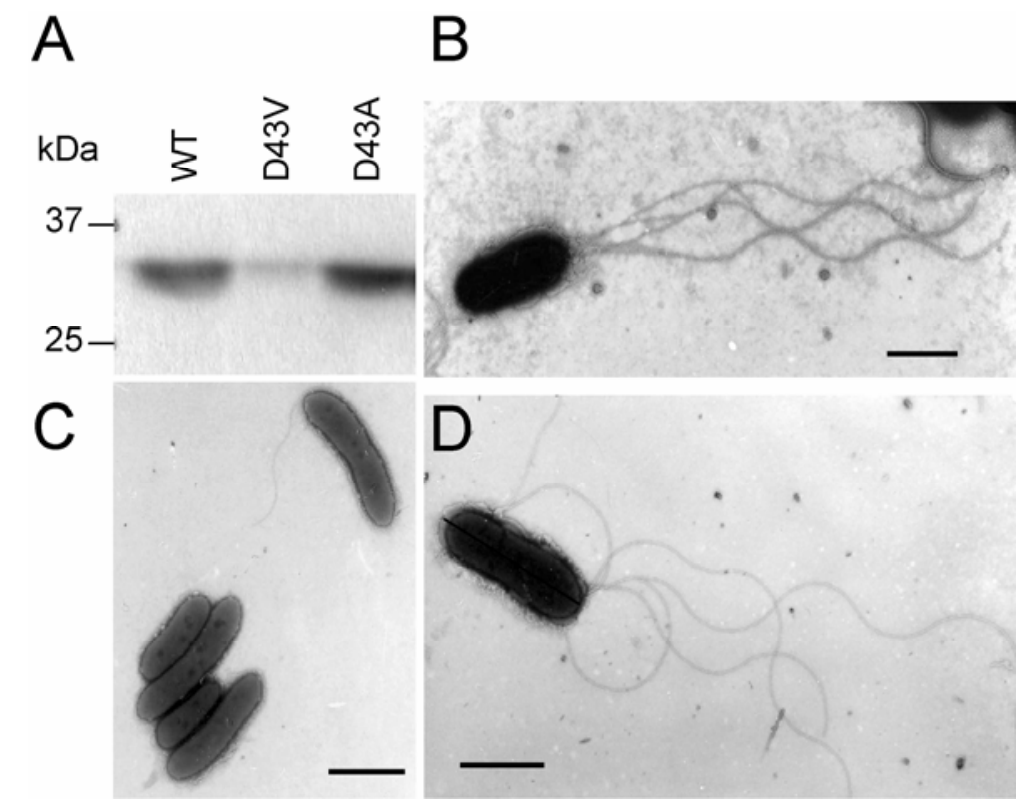

Fig. 7. Detection of flagellin from bacterial bodies and electron microscopic observation of flagella. An overnight culture of each bacterium in Luria-Bertani supplemented with $10 \mathrm{mM} \mathrm{MgCl}$ was subcultured in fresh MMMF medium. Bacterial bodies were harvested from 1 ml of bacterial culture that was adjusted to an optical density at $660 \mathrm{~nm}$ of 0.2 and suspended in $20 \mu \mathrm{l}$ of phosphate-buffered saline with Tween. A, Total proteins of the bacterial bodies were separated by sodium dodecyl sulfate polyacrylamide gel electrophoresis, and flagellin protein was detected by anti-flagellin antibody. Each bacterium was harvested from the overnight culture in MMMF medium and bacterial cells were observed by electron microscopy for the Pseudomonas syringae pv. tabaci B, wild type (WT); C, D43V mutant; and D, D43A mutant. The bar indicates $1 \mu \mathrm{m}$. 
of flagellin in these $P$. syringae strains are identical. However, there is a difference of four amino acids between $P$. aeruginosa and $P$. syringae (Fig. 1). We further found that the elicitor activity of flagellin from $P$. syringae was localized in the $\mathrm{N}$ terminal region containing flg22 by using recombinant flagellin polypeptides (Naito et al. 2007). However, flagellins from $P$. syringae are glycosylated (Taguchi et al. 2003a), and glycosylation of flagellin affects its elicitor activity (Taguchi et al. 2006). Therefore, to properly evaluate the importance of flg 22 in the elicitor activity and bacterial virulence, it is necessary to investigate elicitor activity using not only chemically synthesized oligopeptides and recombinant polypeptides but also purified and glycosylated flagellins from P. syringae.

Compared with the strong abilities of the wild-type flagellin to induce HR cell death (Fig. 2), inhibit seedling growth (Fig. 3), and activate the SIRK promoter (Fig. 4), flagellins purified from $P$. syringae pv. tabaci D43A and D43V had remarkably reduced abilities, indicating that D43 is an important residue for the elicitor activity of flagellin, as previously reported by Sun and associates (2006). When we investigated these activities in different flg22 oligopeptides, both flg22 $2_{\mathrm{Pta}} \mathrm{D} 43 \mathrm{~A}$ and flg22 $2_{\mathrm{Pta}} \mathrm{D} 43 \mathrm{~V}$ had completely lost these abilities. Because flg $22_{\mathrm{Pta}}$ and flg $22_{\mathrm{Pa}}$ retained the elicitor activity, we verified that the flg22 region is a major MAMP. However, flagellins from $P$. syringae pv. tabaci D43A and D43V showed a weak but significant level of activities at $0.1 \mu \mathrm{M}$ concentration. Furthermore, the elicitor activity of flagellins from $P$. syringae pv. tabaci D43A and D43V increased in a dose-dependent manner (Fig. 4A). To check for concomitant contamination of the flagellin preparation with other HR-inducing elicitors, we prepared flagellin from a flagellin-defective mutant, $\Delta$ fliC (Ichinose et al. 2003), using the same method we used to purify flagellin from the wild-type strain. However, the flagellin preparation from the $\triangle$ fliC mutant did not show any elicitor activity in Arabidopsis Col-0 (data not shown). These results indicate that the outside region of D43 in purified flagellin possesses another epitope that contributes to elicitor activity.

Previously, we found that nonglycosylated flagellin from $P$. syringae pv. tabaci $6605 \Delta$ fgtl mutant strain had a reduced ability to induce HR in nonhost soybean cells (Taguchi et al. 2006), indicating that glycosylation of flagellin may affect the elicitor activity of flagellin. On the other hand, the elicitor activity of flagellin and flg22 was completely abolished in the Arabidopsis fls 2 mutant (Fig. 3C and D), indicating that Arabidopsis requires FLS2 in response not only to flg22 but also to flagellin protein. It is still unclear how the glycan of flagellin is involved in the elicitor activity. As we observed in Figure 3, elicitor activity of the glycosylated D43A and D43V flagellins also requires FLS2, which indicates a possible interaction between FLS2 and the outside region of D43 in flagellin.

Although both $P$. syringae pv. tabaci mutants $\mathrm{D} 43 \mathrm{~A}$ and $\mathrm{D} 43 \mathrm{~V}$ had reduced virulence in both the spray inoculation and infiltration inoculation methods (Fig. 5A and C), we observed a reduction of bacterial population in the mutants in the sprayinoculation method (Fig. 5B) but not obviously in the infiltration-inoculation method (Fig. 5D). Previously, we observed similar phenomena; flagellin glycosylation-defective mutants in $P$. syringae pv. tabaci are swarming defective but a reduction of bacterial propagation in the mutant strains was not obvious in the infiltration experiment (Taguchi et al. 2006). The importance of flagellar motility in bacterial virulence was also reported in many other species: Erwinia carotovora subsp. carotovora (Hossain et al. 2005), R. solanacearum (TansKersten et al. 2004), and several pathovars of $P$. syringae
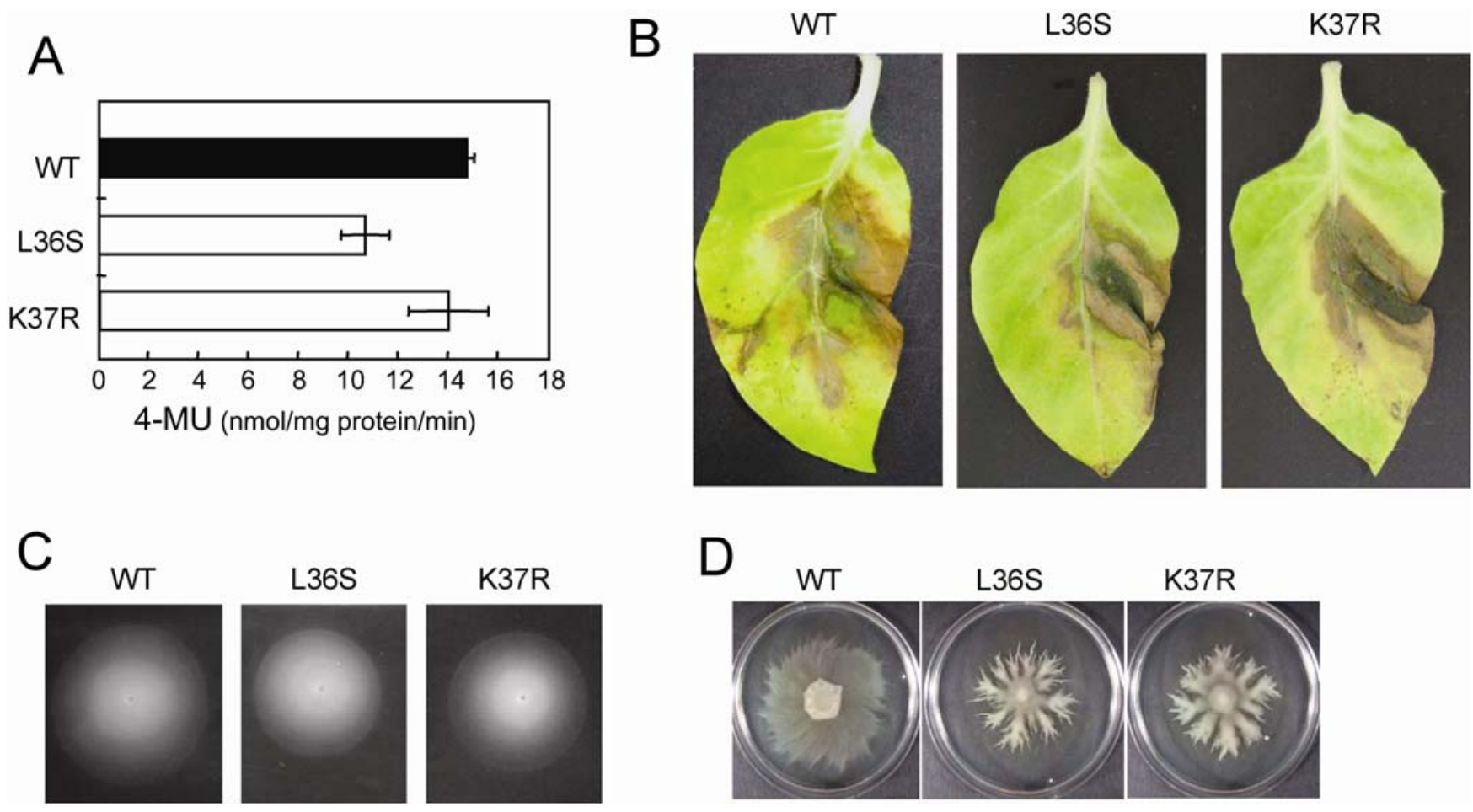

Fig. 8. Effects of L36 and K37 substitutions on elicitor activity, motility, and virulence. A, Flagellin proteins from Pseudomonas syringae pv. tabaci wild type (black box) and L36S- and K37R-substituted mutant strains (white boxes) were infiltrated into the leaves at $0.1 \mu \mathrm{M}$, and senescence-induced receptorlike kinase promoter-derived $\beta$-glucuronidase activity was measured fluorometrically after $24 \mathrm{~h}$ of treatment. B, A virulence assay. Tobacco leaves were infiltration-inoculated with bacteria at $2 \times 1^{05} \mathrm{CFU} / \mathrm{ml}$ and were incubated at $23^{\circ} \mathrm{C}$ for 10 days. C, Swimming motility and $\mathbf{D}$, swarming motility assays. Bacterial cell densities were adjusted to an optical density at $660 \mathrm{~nm}$ of 0.3 with $\mathrm{MMMF}$ medium $\left(50 \mathrm{mM}\right.$ potassium phosphate buffer, $7.6 \mathrm{mM}\left(\mathrm{NH}_{4}\right)_{2} \mathrm{SO}_{4}$, $1.7 \mathrm{mM} \mathrm{MgCl}$, and $1.7 \mathrm{mM} \mathrm{NaCl}, \mathrm{pH} 5.7$, supplemented with $10 \mathrm{mM}$ each of mannitol and fructose), and 3- $\mu$ l aliquots were inoculated on the center of MMMF (0.25\% agar) and SWM ( $0.5 \%$ peptone, $0.3 \%$ yeast extract) agar $(0.5 \%$ agar) plates for swimming and swarming assays, respectively. Each experiment was repeated three times, and typical results were shown in B, C, and D. In A, values represent means and standard errors. 
(Haefele and Lindow 1987; Hattermann and Ries 1989; Panopoulos and Schroth 1974). In P. syringae pv. tabaci, reductions of swimming and swarming motilities and adhesion ability were observed in both mutants D43A and D43V and were especially prominent in the D43V mutant (Fig. 6), because the $\mathrm{D} 43 \mathrm{~V}$ mutant failed to form stable and functional flagella filaments (Fig. 7). Thus, P. syringae pv. tabaci D43A and $\mathrm{D} 43 \mathrm{~V}$ failed to cause disease in host tobacco leaves although their flagellins reduced the elicitor activity that induces plant defense responses.

In animals, Toll-like receptors (TLR) have been identified as receptors for variable MAMPs (Akira et al. 2006). TLR are composed of an LRR extracellular domain, transmembrane domain, and cytoplasmic toll/interleukin-1 receptor domain. Among 13 mouse TLR, TLR5 was identified as a receptor for flagellin (Hayashi et al. 2001). TLR5 recognizes the conserved regions of both $\mathrm{N}$ - and $\mathrm{C}$-termini in flagellin of the gram-negative bacterium Salmonella typhimurium and activates host inflammatory responses (Smith et al. 2003). On the other hand, the $\mathrm{N}$ - and $\mathrm{C}$-terminal regions in flagellin were shown to be important for precise conformation of the flagellar filament and motility by point mutation analyses (Hyman and Trachtenberg 1991; Kanto et al. 1991). Interestingly, mutation in the flagellin epitope recognized by TLR5 resulted in the reduction of motility, indicating that the host immune system recognizes the region of flagellin that is essential for intermolecular interactions within flagellar protofilaments and for flagellar motility (Smith et al. 2003). Furthermore, a mutant of Salmonella flagellin that evades TLR5 recognition but retains motility was engineered by the introduction of an amino acid replacement at the D0 conserved region into the motility-defective mutant strain (Andersen-Nissen et al. 2005). Thus, evasion of TLR5 by flagellated bacteria might be an evolutional strategy to overcome host immune responses. However, there is no other nucleotide substitution except D43 in the entire fliC gene of D43V, D43A, L36S, and K37R mutants (data not shown), indicating that compensatory mutation to restore bacterial motility did not occur outside D43. These results indicate that bacteria with D43A flagellin are still reasonably motile and their flagellin still has some elicitor activity, whereas bacteria with L36S and K37R flagellin are very motile and their flagellin has higher elicitor activity.

In addition to MAMPs, Mackey and McFall (2006) have proposed the term microbe-induced molecular patterns (MIMPs). MIMPs are categorized as modifications of hostderived molecules that are induced by the intrinsic activity of a pathogen-derived effector and are perceived by a host-defense receptor (Mackey and McFall 2006). MAMPs are molecular patterns directly perceived via direct interactions with a host defense receptor. Mackey and McFall further refined the definition of MAMPs as molecular patterns recognized independently of the microbial molecule's intrinsic activity (Mackey and McFall 2006). From the results of our study and the study of animal TLR5 and flagellins of animal pathogens, we propose that the MAMP site that is recognized may be (and, perhaps, often should be) a site that is central to the biological activity of MAMPs. Thus, the immune system has evolved an ability to precisely target a conserved site on flagellin that is essential for bacterial motility and virulence.

\section{MATERIALS AND METHODS}

\section{Plant materials.}

Arabidopsis thaliana ecotype Columbia-0 wild-type and its $f l s 2$ mutant were used in this study. The fls 2 mutant $(f l s 2-4$, SALK_093905) was obtained as T-DNA insertion mutants from the Salk Institute (Alonso et al. 2003). The homozygous mutation of FLS2 was confirmed by PCR and sequencing of the insertion site. The insertion site of $f l s 2-4$ was located in the coding region of the first exon. The plants were grown at $22^{\circ} \mathrm{C}$ with a 16-h photoperiod. Four-week-old Arabidopsis was used for cell death assay. Tobacco plants (Nicotiana tabacum L. cv. Xanthi NC) were grown at $26^{\circ} \mathrm{C}$ with a 16 -h photoperiod. For inoculation experiments, 2- to 3-month-old plants were used.

\section{Bacterial culture conditions.}

P. syringae pv. tabaci 6605 wild-type and D43-substituted mutant strains were maintained in King's B (KB) medium at $27^{\circ} \mathrm{C}$ and E. coli strains were grown at $37^{\circ} \mathrm{C}$ in Luria-Bertani (LB) medium. To measure bacterial growth, the strains of $P$. syringae pv. tabaci were cultured overnight in LB with $10 \mathrm{mM}$ $\mathrm{MgCl}_{2}$, adjusted to an optical density at $660 \mathrm{~nm}\left(\mathrm{OD}_{660}\right)$ of 0.1 , and subcultured in fresh MMMF medium $(50 \mathrm{mM}$ potassium phosphate buffer, $7.6 \mathrm{mM}\left(\mathrm{NH}_{4}\right)_{2} \mathrm{SO}_{4}, 1.7 \mathrm{mM} \mathrm{MgCl}$, and 1.7 $\mathrm{mM} \mathrm{NaCl}, \mathrm{pH} 5.7$, supplemented with $10 \mathrm{mM}$ each of mannitol and fructose). The cell density was measured sequentially by absorbance at $\mathrm{OD}_{660}$.

\section{Inoculation experiments.}

For the spray-inoculation experiments, overnight cultured bacterial strains in M9 medium with $0.2 \%$ glucose were harvested after centrifugation, then suspended in $10 \mathrm{mM} \mathrm{MgSO}_{4}$ and $0.02 \%$ Silwet L77 (OSI Specialties, Danbury, CT, U.S.A.) at a density of $2 \times 10^{8} \mathrm{CFU} / \mathrm{ml}$. Both leaf surfaces were inoculated and the leaves were incubated in $100 \%$ humidity for 1 day and $80 \%$ humidity for 9 to 10 days in a growth cabinet at $23^{\circ} \mathrm{C}$. For inoculation by the syringe-infiltration method, overnight cultured bacterial strains were suspended in $10 \mathrm{mM}$ $\mathrm{MgSO}_{4}$ at a density of $2 \times 10^{5} \mathrm{CFU} \mathrm{ml}{ }^{-1}$; then, bacteria were infiltrated into the leaves using a needleless syringe. To measure bacterial populations in inoculated plant leaves, each inoculated leaf was soaked in $15 \% \mathrm{H}_{2} \mathrm{O}_{2}$ for 1 min to sterilize the leaf surface; then, leaves were washed with sterile distilled water. Five leaf disks ( $8 \mathrm{~mm}$ in diameter) were punched from each leaf and ground in a mortar with a pestle. Serially diluted bacterial suspensions in sterilized water were spread on $\mathrm{KB}$ plates. Two days later, the numbers of colonies was counted and bacterial populations were calculated.

\section{Generation of mutant strains.}

To introduce the desired point mutations, a QuikChange XL site-directed mutagenesis kit (Stratagene, La Jolla, CA, U.S.A.) was used. The entire $f l i C$ region amplified by PCR as described by Taguchi and associates (2006) was inserted into the mobilizable cloning vector pK18mobSacB (Schäfer et al. $1994)$ via the BamHI site. This double-stranded DNA vector was used as the template. Two sets of complementary oligonucleotides containing the replacements D43V-FW (5'-caacagc gccaaaGTTGACgctgccggcc-3') and D43V-RV (5'-ggccggcagc GTCAACtttggegctgttg- $\left.3^{\prime}\right)$ and D43A-FW (5'-caacagcgecaa AGLCTgacgctgccggcc- $3^{\prime}$ ) and D43A-RV (5'-ggccggcagcgtc A $\underline{\text { GCTttggcgctgttg- }} 3^{\prime}$ ) were synthesized (underlines indicate the replaced nucleotide and capital letters indicate HincII or AluI sites). Subsequently, PCR, DpnI digestion, and transformation were performed according to the manufacturer's instructions. The desired mutations were confirmed by DNA sequence analysis; then, mutated plasmids were introduced into E. coli S17-1 and introduced into $P$. syringae pv. tabaci 6605 by conjugation. After loss of the plasmid by incubation on $\mathrm{KB}$ agar plates containing $10 \%$ sucrose, each mutant strain was isolated. The mutated $f l i C$ gene generated an additional HincII site in the corresponding positions at D43V and the AluI site at D43A. Therefore, analysis of restriction fragment length polymorphism in PCR-amplified $f l i C$ gene revealed that 
each mutant strain possesses a mutated fliC gene without the wild-type gene. Mutation of the $f l i C$ gene was also confirmed by direct sequencing of the PCR product and the mutant strains were designated D43V or D43A.

In the same way, site-directed mutagenesis for L36S and K37R was carried out using sets of primers L36S-FW (5'-tcgtct gtcttccggttcgaaaatcaacagcgcc-3') and L36S-RV (5'-ggcgctgttgat tttcgaaccggaagacagacga-3') and K37R-FW (5'-tgtcttccggtctgaga atcaacagcgccaa- $\left.3^{\prime}\right)$ and K37R-RV (5'-ttggcgctgttgattctcagaccgg aagaca- $3^{\prime}$ ) (underlines indicate the replaced nucleotide). All specific mutations of the $f l i C$ gene were confirmed by direct sequencing of PCR products from the mutants.

\section{Purification of flagellin proteins and oligopeptides.}

All Pseudomonas strains were inoculated in LB medium supplemented with $10 \mathrm{mM} \mathrm{MgCl}$ for $24 \mathrm{~h}$ at $25^{\circ} \mathrm{C}$. The bacterial cells were harvested by centrifugation $(3,000 \mathrm{rpm}, 10$ min), suspended in one-quarter volume of MMMF medium, and incubated for $24 \mathrm{~h}$ at $23^{\circ} \mathrm{C}$. After incubation, a $10 \%$ volume of $20 \%$ polyethylene glycol (PEG) (6000) to $1 \mathrm{M} \mathrm{NaCl}$ solution was added to the bacterial culture. The bacterial cells were harvested by centrifugation $(10,000 \mathrm{rpm}, 20 \mathrm{~min})$ and suspended in $300 \mu \mathrm{l}$ of phosphate-buffered saline buffer (137 $\mathrm{mM} \mathrm{NaCl}, 8.1 \mathrm{mM} \mathrm{Na}_{2} \mathrm{HPO}_{4}, 2.68 \mathrm{mM} \mathrm{KCl}$, and $1.47 \mathrm{mM}$ $\mathrm{KH}_{2} \mathrm{PO}_{4}$ ) per $100 \mathrm{ml}$ of bacterial culture. Flagella were then sheared off by vortexing. After centrifugation at $10,000 \mathrm{rpm}$ for $5 \mathrm{~min}$, a $10 \%$ volume of $20 \%$ PEG (6000)/1 M NaCl solution was added to the supernatant, and the supernatant was incubated on ice for $20 \mathrm{~min}$. Subsequently, flagella were harvested by centrifugation at $12,000 \mathrm{rpm}$ for $30 \mathrm{~min}$, and the pellet was suspended in distilled water. The resultant flagella were further purified by centrifugation at $40,000 \mathrm{rpm}$ for 30 min. The precipitated flagella, which consist of flagellin proteins, were dissociated in $0.1 \mathrm{M}$ glycine- $\mathrm{HCl}$ buffer $(\mathrm{pH} 2.0)$ and centrifuged at $40,000 \mathrm{rpm}$ for $30 \mathrm{~min}$. The buffer of the flagellin solution in the supernatant was replaced with distilled $\mathrm{H}_{2} \mathrm{O}$ by use of a spin column (VIVASPIN 20 [30,000 MWCO PES]; Vivascience, Hanover, Germany). The molecular weight, quality, and quantity of the purified flagellin were confirmed by the Bradford method and SDS-PAGE analysis. The oligopeptides flg22 2 , flg22 $2_{\mathrm{Pta}}$, flg22 $2_{\mathrm{Pta}} \mathrm{D} 43 \mathrm{~A}$, and flg22 $2_{\mathrm{Pta}} \mathrm{D} 43 \mathrm{~V}$ were chemically synthesized by Hokkaido System Science (Sapporo, Japan).

\section{Detection of dead cells.}

The dead cells in the leaves were stained with lactophenoltrypan blue according to the methods described by Koch and Slusarenko (1990) and Naito and associates (2007). Whole leaves were boiled for approximately $3 \mathrm{~min}$ in the staining solution and decolorized in chloral hydrate solution at $2.5 \mathrm{~g}$ $\mathrm{ml}^{-1}$ for at least $6 \mathrm{~h}$.

\section{Growth inhibition assay of Arabidopsis seedlings.}

Growth inhibition assays of Arabidopsis seedlings were performed as described by Gómez-Gómez and associates (1999). Sterilized Arabidopsis seed were sown on $0.4 \%$ agar containing the salts of Murashige-Skoog (MS) medium (Wako, Osaka, Japan), Gamborg's vitamin solution (Sigma-Aldrich, St. Louis), $0.05 \%$ morpholineethanesulfonic acid, and $1 \%$ sucrose at $\mathrm{pH} 5.7$ and incubated at $24^{\circ} \mathrm{C}$ with a 16-h photoperiod. Seedlings grown for 5 days on MS agar plates were transferred to liquid MS medium supplied with each flagellin or flg22 at a final concentration of $0.1 \mu \mathrm{M}$ or water as a control (two seedlings per $400 \mu \mathrm{l}$ of MS medium in one well of a 24-well plate). After 7 days of incubation at $24^{\circ} \mathrm{C}$ with a $16-\mathrm{h}$ photoperiod, the seedlings were photographed and the fresh weight was measured.

\section{Fluorometric measurement and histochemical analysis} of GUS activity.

Transgenic Arabidopsis Col-0 possessing the SIRKp:GUS chimeric gene was provided by Dr. S. Robatzek (Kunze et al. 2004). Quantitative analysis of GUS enzymatic activities was carried out using the extracts from leaves of transgenic plants. Five leaf disks ( $5 \mathrm{~mm}$ in diameter) were punched from each leaf infiltrated with flagellin and flg22 oligopeptides and ground in a mortar with a pestle. The concentrations of proteins in the crude enzyme solution obtained were determined by the method of Bradford, and GUS-specific activity (nmol of 4-MU produced per minute per milligram of protein) was determined using 4methylumbelliferyl- $\beta$-D-glucronide as the substrate, according to the previously described method (Jefferson et al. 1987). Histochemical GUS analysis was performed with leaves. Punched leaf disks were prefixed in $1 \%$ formaldehyde in $50 \mathrm{mM}$ phosphate buffer ( $\mathrm{pH}$ 7.0) and rinsed three times in the same buffer without formaldehyde. GUS staining was performed using 5bromo-4-chloro-3-indolyl- $\beta$-D-glucuronide as the substrate as described (Jefferson et al. 1987).

\section{Western blot analysis.}

To detect flagellin in each bacterial cell, total proteins were prepared and subjected to $12 \%$ SDS-PAGE. Then, using antiflagellin antibody, flagellin was detected as described previously (Taguchi et al. 2003b).

\section{Motility assay and adhesion experiment.}

Bacterial cells grown in LB supplemented with $10 \mathrm{mM}$ $\mathrm{MgCl}_{2}$ at $25^{\circ} \mathrm{C}$ were adjusted to an $\mathrm{OD}_{660}$ of 0.3 in $\mathrm{MMMF}$ medium. For the swimming assay, $3 \mu \mathrm{l}$ of bacterial suspension was inoculated in the center of the $0.25 \%$ agar MMMF plates and incubated at $23^{\circ} \mathrm{C}$ for 2 days. For the swarming assay, bacteria were inoculated on SWM plates $(0.5 \%$ peptone, $0.3 \%$ yeast extract, $0.5 \%$ agar; Difco Laboratories, Detroit) and incubated at $27^{\circ} \mathrm{C}$ for 1 day (Taguchi et al. 2006). Adhesion was measured as described previously (Taguchi et al. 2006). Briefly, density-adjusted aliquots of overnight cultures of each bacterial strain were transferred to polystyrene microtiter plate wells and bacteria were incubated at $27^{\circ} \mathrm{C}$ for $48 \mathrm{~h}$. After washing to remove loosely bound bacteria, adherent bacteria were stained with crystal violet. The amount of crystal violet eluted from stained bacteria was measured at $\mathrm{OD}_{595}$.

\section{Transmission electron microscopy.}

The overnight culture of each bacterium in MMMF medium was observed under an electron microscope (H-7500, Hitachi, Tokyo) as described previously (Taguchi et al. 2008).

\section{ACKNOWLEDGMENTS}

We thank the Leaf Tobacco Research Laboratory of Japan Tobacco, Inc. and the Salk Institute for providing $P$. syringae pv. tabaci 6605 and $A$. thaliana Columbia fls 2 mutant, respectively. We are also grateful to $\mathrm{S}$. Robatzek (Max-Planck-Institute für Züchtungsforschung, Köln, Germany) for the kind gift of seed of transgenic Arabidopsis Col-0 possessing the SIRKp:GUS chimeric gene. This work was supported in part by Grants-inAid for Scientific Research (B) (No. 18380035) from the Ministry of Education, Culture, Sports, Science and Technology of Japan and the Program for Promotion of Basic Research Activities for Innovative Bioscience (PROBRAIN).

\section{LITERATURE CITED}

Akira, S., Uematsu, S., and Takeuchi, O. 2006. Pathogen recognition and innate immunity. Cell 124:783-801.

Alonso, J. M., Stepanova, A. N., Leisse, T. J., Kim, C. J., Chen, H., Shinn, P., Stevenson, D. K., Zimmerman, J., Barajas, P., Cheuk, R., Gadrinab, C., Heller, C., Jeske, A., Koesema, E., Meyers, C. C., Parker, H., Prednis, 
L., Ansari, Y., Choy, N., Deen, H., Geralt, M., Hazari, N., Hom, E., Karnes, M., Mulholland, C., Ndubaku, R., Schmidt, I., Guzman, P., Aguilar-Henonin, L., Schmid, M., Weigel, D., Carter, D. E., Marchand, T., Risseeuw, E, Brogden, D., Zeko, A., Crosby, W. L., Berry, C. C., and Ecker, J. R. 2003. Genome-Wide Insertional mutagenesis of Arabidopsis thaliana. Science 301:653-657.

Andersen-Nissen, E., Smith, K. D., Strobe, K. L., Barrett, S. L., Cookson, B. T., Logan, S. M., and Aderem, A. 2005. Evasion of Toll-like receptor 5 by flagellated bacteria. Proc. Natl. Acad. Sci. U.S.A. 102:92479252.

Asai, T., Tena, G., Plotnikova, J., Willmann, M. R., Chiu, W. L., GomezGomez, L., Boller, T., Ausubel, F. M., and Sheen, J. 2002. MAP kinase signalling cascade in Arabidopsis innate immunity. Nature 415:977983.

Bent, A. F., and Mackey, D. 2007. Elicitors, effectors, and $R$ genes: The new paradigm and a lifetime supply of questions. Annu. Rev. Phytopathol. 45:399-436.

Bittel, P., and Robatzek, S. 2007. Microbe-associated molecular patterns (MAMPs) probe plant immunity. Curr. Opin. Plant Biol. 10:335-341.

Chinchilla, D., Bauer, Z., Regenass, M., Boller, T., and Felix, G. 2006. The Arabidopsis receptor kinase FLS2 binds flg22 and determines the specificity of flagellin perception. Plant Cell 18:465-476.

Felix, G., Duran, J. D., Volko, S., and Boller, T. 1999. Plants have a sensitive perception system for the most conserved domain of bacterial flagellin. Plant J. 18:265-276.

Gómez-Gómez, L., and Boller, T. 2000. FLS2: An LRR receptor-like kinase involved in the perception of the bacterial elicitor flagellin in Arabidopsis. Mol. Cell 5:1003-1011.

Gómez-Gómez, L., Felix, G., and Boller, T. 1999. A single locus determines sensitivity to bacterial flagellin in Arabidopsis thaliana. Plant $\mathrm{J}$. $18: 277-284$

Haefele, D. M., and Lindow, S. E. 1987. Flagellar motility confers epiphytic fitness advantages upon Pseudomonas syringae. Appl. Environ. Microbiol. 53:2528-2533.

Hattermann, D. R., and Ries, S. M. 1989. Motility of Pseudomonas syringae pv. glycinea and its role in infection. Phytopathology 79:284-289.

Hayashi, F., Smith, K. D., Ozinsky, A., Hawn, T. R., Yi, E. C., Goodlett, D. R., Eng, J. K., Akira, S., Underhill, D. M., and Aderem, A. 2001. The innate immune response to bacterial flagellin is mediated by Tolllike receptor 5. Nature 410:1099-1103.

Hossain, M. M., Shibata, S., Aizawa, S., and Tsuyumu, S. 2005. Motility is an important determinant for pathogenesis of Erwinia carotovora subsp. carotovora. Physiol. Mol. Plant Pathol. 66:134-143.

Hyman, H. C., and Trachtenberg, S. 1991. Point mutations that lock Salmonella typhimurium flagellar filaments in the straight right-handed and left-handed forms and their relation to filament superhelicity. J. Mol. Biol. 220:79-88.

Ichinose, Y., Shimizu, R., Ikeda, Y., Taguchi, F., Marutani, M., Mukaihara, T., Inagaki, Y., Toyoda, K., and Shiraishi, T. 2003. Need for flagella for complete virulence of Pseudomonas syringae pv. tabaci: Genetic analysis with flagella-defective mutants $\Delta f l i C$ and $\Delta f l i D$ in host tobacco plants. J. Gen. Plant Pathol. 69:244-249.

Jefferson, R. A., Kavanagh, T. A., and Bevan, M. W. 1987. GUS fusions: Beta-glucuronidase as a sensitive and versatile gene fusion marker in higher plants. EMBO (Eur. Mol. Biol. Organ.) J. 6:3901-3907.

Kanto, S., Okino, H., Aizawa, S., and Yamaguchi, S. 1991. Amino acids responsible for flagellar shape are distributed in terminal regions of flagellin. J. Mol. Biol. 219:471-480.

Koch, E., and Slusarenko, A. 1990. Arabidopsis is susceptible to infection by a downy mildew fungus. Plant Cell 2:437-445.

Kunze, G., Zipfel, C., Robatzek, S., Niehaus, K., Boller, T., and Felix, G.
2004. The $\mathrm{N}$ terminus of bacterial elongation factor $\mathrm{Tu}$ elicits innate immunity in Arabidopsis plants. Plant Cell 16:3496-507.

Mackey, D., and McFall, A. J. 2006. MAMPs and MIMPs: Proposed classifications for inducers of innate immunity. Mol. Microbiol. 61:13651371.

Meindl, T., Boller, T., and Felix, G. 2000. The bacterial elicitor flagellin activates its receptor in tomato cells according to the address-message concept. Plant Cell 12:1783-1794.

Naito, K., Ishiga, Y., Toyoda, K., Shiraishi, T. and Ichinose, Y. 2007. Nterminal domain including conserved flg22 is required for flagellininduced hypersensitive cell death in Arabidopsis thaliana. J. Gen. Plant Pathol. 73:281-285.

Nürnberger, T., Brunner, F., Kemmerling, B., and Piater, L. 2004. Innate immunity in plants and animals: Striking similarities and obvious differences. Immunol. Rev. 198:249-266.

Panopoulos, N. J., and Schroth, M. N. 1974. Role of flagellar motility in the invasion of bean leaves by Pseudomonas phaseolicola. Phytopathology 64:1389-1397.

Pfund, C., Tans-Kersten, J., Dunning, F. M., Alonso, J. M., Ecker, J. R., Allen, C., and Bent, A. F. 2004. Flagellin is not a major defense elicitor in Ralstonia solanacearum cells or extracts applied to Arabidopsis thaliana. Mol. Plant-Microbe Interact. 17:696-706.

Robatzek, S., and Somssich, I. E. 2002. Targets of AtWRKY6 regulation during plant senescence and pathogen defense. Genes Dev. 16:11391149 .

Schäfer, A., Tauch, A., Jäger, W., Kalinowski, J., Thierbach, G., and Pühler, A. 1994. Small mobilizable multi-purpose cloning vectors derived from the Escherichia coli plasmids pK18 and pK19: Selection of defined deletions in the chromosome of Corynebacterium glutamicum. Gene 145:69-73.

Smith, K. D., Andersen-Nissen, E., Hayashi, F., Strobe, K., Bergman, M. A., Barrett, S. L., Cookson, B. T., and Aderem, A. 2003. Toll-like receptor 5 recognizes a conserved site on flagellin required for protofilament formation and bacterial motility. Nat. Immunol. 4:1247-1253.

Sun, W., Dunning, F. M., Pfund, C., Weingarten, R., and Bent, A.F. 2006. Within-species flagellin polymorphism in Xanthomonas campestris pv. campestris and its impact on elicitation of Arabidopsis FLAGELLIN SENSING2-dependent defenses. Plant Cell 18:764-779.

Taguchi, F., Shimizu, R., Inagaki, Y., Toyoda, K., Shiraishi, T., and Ichinose, Y. 2003a. Post-translational modification of flagellin determines the specificity of HR induction. Plant Cell Physiol. 44:342-349.

Taguchi, F., Shimizu, R., Nakajima, R., Toyoda, K., Shiraishi, T., and Ichinose, Y. 2003b. Differential effects of flagellins from Pseudomonas syringae pv. tabaci, tomato and glycinea on plant defense response. Plant Physiol. Biochem. 41:165-174.

Taguchi, F., Takeuchi, K., Katoh, E., Murata, K., Suzuki, T., Marutani, M., Kawasaki, T., Eguchi, M., Katoh, S., Kaku, H., Yasuda, C., Inagaki, Y., Toyoda, K., Shiraishi, T., and Ichinose, Y. 2006. Identification of glycosylation genes and glycosylated amino acids of flagellin in Pseudomonas syringae pv. tabaci. Cell. Microbiol. 8:923-938.

Taguchi, F., Shibata, S., Suzuki, T., Ogawa, Y., Aizawa, S., Takeuchi, K., and Ichinose, Y. 2008. Effects of glycosylation on swimming ability and flagella polymorphic transformation of Pseudomonas syringae pv. tabaci 6605. J. Bacteriol. 190:764-768.

Takeuchi, K., Taguchi, F., Inagaki, Y., Toyoda, K., Shiraishi, T., and Ichinose, Y. 2003. Flagellin glycosylation island in Pseudomonas syringae pv. glycinea and its role in host specificity. J. Bacteriol. 185:66586665

Tans-Kersten, J., Brown, D., and Allen, C. 2004. Swimming motility, a virulence trait of Ralstonia solanacearum, is regulated by FlhDC and the plant host environment. Mol. Plant-Microbe Interact. 17:686-695. 